\title{
白金陽極での酢酸塩水溶液の電解酸化反応における $\mathrm{pH}$ の影響*
}

\author{
関根 \\ Effect of pH on Electrolytic Oxidation at Platinum and \\ Other Anodes in Aqueous Acetate Solutions*
}

功**

\author{
Isao SEKINE**
}

\begin{abstract}
The current-potential curves of platinum, gold, palladium, lead dioxide, and graphite anodes were measured by means of the potential sweep method in aqueous mixtures of sulfate, with or without addition of acetate, and at various $\mathrm{pH}^{\prime} \mathrm{s}$.

In acetate-free solutions, constant build up potentials due to the discharge of hydroxyl ions were observed in the range of $\mathrm{pH}=2 \sim 5$, not only at platinum but also at all the other anode materials.

In acetate solutions containing sulfate, build up potentials of a platinum electrode shifted to an anodic potential with increasing acetate concentration at $\mathrm{pH}^{\prime} \mathrm{s}$ lower than 5 . These facts suggest a possibility that the Kolbe reaction takes place in the weakly acid region.

The coverage $\theta$ of acetate ions on a platinum anode at $\mathrm{pH} 3$ and 5 reached a constant value in solutions of $1 M$ acetate concentration, and $\theta$ approached unity with increasing anodic potential. These adsorption values obeyed the Langmuir adsorption isotherm.
\end{abstract}

\section{1 緒 言 (Introduction)}

著者らはこれまで酶酸塩やプロピオン酸塩溶液での陽 極反応の機構を調べるために，前報》では支持電解液と しての硫酸塩または硝酸塩水溶液, および酶酸塩添加溶 液中で各種陽極についての界面微分容量を交流ブリッジ 法で測定した結果について述べた.このとき特に水酸イ オンの影響，すなわち水酸イオンの放電による酸素発生 反応について検討した。

さてこれまでに使用してきた電解液について考えてみ ると, 電解液はすべて弱酸性のふんい (雾团) 気で実験 を行ってきた. 特に電解液の $\mathrm{pH}$ については, 強酸性で は酷酸の解離が困難となり, 逆に強アルカリ性では水酸 イオンの放電による酸素の発生が活発となるのは容易に 考えられる。しかしながら，弱アルカリ性では酶酸塩の ときは Hofer-Moest 反応によりメチルアルコールがか なり顕著に生成するので, コルベ二量化反応だけについ ていえば弱酸性の状態が最む起りやすい条件とされてい $る^{22}$.

* 昭和 46 年 10 月篦気化学協会北陸支部秋李大会 (長岡) にて発表

** 東京理科大学理工学部 (千菜県野田市山崎東龟山) Faculty of Science and Technology, Science University of Tokyo(Yamazaki, Noda, Chiba)
本報では，コルベ反応が起る白金陽極での水酸イオン や䣷酸イオンの電解酸化反忘に及ぼす影響名さらに詳し く調べるために，試料液の $\mathrm{pH}$ を変えた上きの電流電 位曲線を測定した。また比較参考のために特別な条件で しかコルベ反応が起らない金やパラジウム，それに異常 コルベ反応の起る二酸化鉛および黒鉛陽極についても测 定した.そしてこの曲線より陽極反応開始に伴う電流の 立ち上がりを示寸電位（以下立ち上がり電位という）を 解析した．また分極曲線より酶酸イオンの電極面への被 覆率 $\theta$ を求めて考察した.この結果, 白金ではコル ベ二量化反忘の条件として $\mathrm{pH}$, 電位, 酶酸イオンの源 度が挙げられているが，これらの関連が説明可能となっ た.

\section{2 実験 (Experimental)}

\section{1 菱置および方法}

用いた試料陽極注前報了之同様，白金，金，パラジウ ム，二酸化鉛㧍よび黒鉛であり，これら電極面の前処理 も同様に行った。電流-電位曲線の測定は電位走查法に より，用いたポテンシオスタットは北斗電工のPS-500B である.この電位走查速度は $200 \mathrm{mV} / \mathrm{sec}$ で, 測定電位 


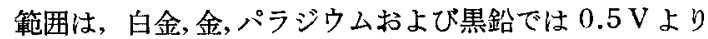
$2.3 \mathrm{~V}$ 付近まで，また二酸化鉛では $1.0 \mathrm{~V}$ より $2.3 \mathrm{~V}$ 付 近までである。なお $2.3 \mathrm{~V}$ 付近で再現性がないときは， $2.3 \mathrm{~V}$ より卑な電位のところまでにした。このようにし て記録計のペンを 連続的に 3 回往復させて電流-電位曲 線を測定した。この曲線より立ち上がり電位の決定は電 流密度を一定にしたときの值を求めた。このとき，白 金，金，パラジウムでは $15.9 \mathrm{~mA} / \mathrm{cm}^{2}$ ，二酸化鉛では $0.855 \mathrm{~mA} / \mathrm{cm}^{2}$ ，扎よで黒鉛では $3.98 \mathrm{~mA} / \mathrm{cm}^{2}$ の電流 密度を一定にしたときの電位を平均してそれぞれの立ち 上がり電位とした．ただし，二酸化鉛のブランク液につ いでは $0.428 \mathrm{~mA} / \mathrm{cm}^{2}$ での立ち上がり電位を採用した.

\section{2 電解夜の調製}

試料液は前報1で用いたのと同様， $0.5 M$ 硫酸カリウ ム水溶液（ブランク液）にいろいろな濃度の酶酸と酢酸 カリウムの等モル混合水溶液を加えて使用した块．酶酸 塩水溶液の濃度は $0.01 \mathrm{M}, 0.05 \mathrm{M}, 0.1 \mathrm{M}, 0.5 \mathrm{M}, 1$ $M$ および $5 M$ である. 各濃度の酢酸塩水溶液と $0.5 M$ 硫酸カリウム水溶液との混合溶液をおのおのの $\mathrm{pH}$ に調 整した液が試料液である。 $\mathrm{pH}$ の值は $1,3,5,7,9$, 11 および 13 の 7 点を目標にした. この $\mathrm{pH}$ の調整は, $\mathrm{pH}$ が 7 以下のときは $0.5 \mathrm{M}$ 硫酸を使用し, また, $\mathrm{pH}$ が 7 以上では $0.5 M$ 水酸化カリウム水溶液を使用して 調整した.これら $\mathrm{pH} の$ 測定は東亜電波のガラス電極 $\mathrm{pH}$ 計 HM-5A で行った。な拉，用いた試薬はす心゙て 市販特級のもので，そのまま使用した。測定温度は 25 $\pm 0.5^{\circ} \mathrm{C}$ である.

\section{3 結果および考察 (Results and Discussion)}

\section{1 陽極反応の立ち上がり電位}

$0.5 M$ 硫酸カリウム水溶液 (ブランク液) 中での各電 極についての立ち上がり電位と $\mathrm{pH}$ との関係は, $\mathrm{pH}$ を 1〜5, 5 10, および 10 13 の 3 つの領域に分けられ る.

まず $\mathrm{pH}$ が 5 以下のとき，電位は各電極特有の一定値 を示した.一定の電位は, パラジウムでは $1.40 \mathrm{~V}$, 白金 では $1.53 \mathrm{~V}$, 黒鉛では $1.55 \mathrm{~V}$, 金では $1.67 \mathrm{~V}$, 二酸化 鉛では $1.97 \mathrm{~V}$ を示し, 上記の順に貴となっていた。こ のように示された電位の順序は, 前報”の単一パルス法 による $5 M$ 酶酸塩水溶液についての分極曲線でも電流 密度を $1 \mathrm{~mA} / \mathrm{cm}^{2}$ と一定にとったとき，パラジウムでは $1.0 \mathrm{~V}$, 黒鉛では $1.31 \mathrm{~V}$, 白金では $1.49 \mathrm{~V}$, 金では $1.51 \mathrm{~V}$ および二酸化鉛では $1.68 \mathrm{~V}$ を示したのとだいたいよく 対応していた. したがって $\mathrm{pH}$ が 2 5 の籁囲では, 水 酸イオンの放電による酸素発生の電位はそれぞれの電極

*1 たとえは酶酸塩水溶液港度 $1 M$ とい $30 は 0.5 M \mathrm{~K}_{2} \mathrm{SO}_{4} 50 \mathrm{~m} l$ 十 (1 $\left.M \mathrm{CH}_{8} \mathrm{COOH}+1 M \mathrm{CH}_{3} \mathrm{COOK}\right) 50 \mathrm{ml}$ の溶液で古る.
についてほぼ一定値を示し， $\mathrm{pH}$ の変化によってあまり 変わらないことが認められた。

また $\mathrm{pH}$ が 7.5 における電位は極小值を示した。こ の極小は何に基ぶくものか，いまのところ不明である が，後述の上うに䣷酸イオンが加わる上一般的には極小 は観察されなくなるので，興味ある現象上も考えられ ろ.

つぎに $\mathrm{pH}$ が 10 以上について，特に白金，パラジウ ムおよび黒鉛では $\mathrm{pH} か ゙ 13$ のとき約 $1.3 \mathrm{~V}$ に収束する 傾向が観测された，強厂ルカリ性，特に $\mathrm{pH}$ が 13 では ほとんどの反応が水酸イオンの放電による酸素の発生で あって，これがいっそう活発であると考えられるので， このときの立ち上がり電位はかなりはっきりした酸素発 生だけの本来の電位を示していると思わ机る。 $\mathrm{pH}$ が 13 での電位は，金は $1.45 \mathrm{~V}$ ，白金は $1.32 \mathrm{~V}$ およびパラジ ウム注 $1.30 \mathrm{~V}$ という值は，すでに前報4でも示したよ らに, Will ららの酸素発生電位として金は $1.55 \mathrm{~V}$ ，白 金は $1.35 \mathrm{~V}$ 拉よびパジジムでは $1.25 \mathrm{~V}$ の值にかな

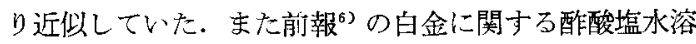
液中での分極曲楾でも，電流が流れ始好た電位は $1.3 \mathrm{~V}$ であった.なお Hoare による酸素飽和の $2 N$ 硫酸中で 得られた分極曲線でも酸素発生の開始電位は金では 1.36 $\mathrm{V}^{7}$ ，白金では $1.23 \mathrm{~V}^{8) ， ハ ゚ ラ シ ゙ ウ ム て ゙ は ~} 1.20 \mathrm{~V}^{9}$ であ ると報告されていることから䒯えても，白金では $1.3 \mathrm{~V}$ 付近に酸素発生電位がもるのは, 測定法の差による電流 密度の因子考慮すればほぼ妥当であ万らと考えられ る. 去れゆえ他の電極についての $\mathrm{pH}$ が 13 での酸素発 生の立ち上がり電位も，かなり妥当性があると考元られ る.

Fig. 1 と Fig. 2 はブランク液に酶酸塩を含んだとき の白金と金についての立ち上がり電位上 $\mathrm{pH}$ との関保 を示す.

白金電極 (Fig. 1) で，酢酸塩を加えるとブランク 液の電位より貴となり，酶酸塩の浱度が高くなるほど， すなわち最低濃度の短い破線より最高濃度の長い破線一 と， $\mathrm{pH}$ の全域で立ち上がり電位は一般に貴な電位汇移 行した. 特に $\mathrm{pH}$ が 5 以下では電位が濃度に依存し, 規 則的に変化している、この事実は，すでに Sugino ら ${ }^{10)}$ による定電位電解による研究に打いても指摘されている 上うに, 弱酸性域でコルベ反応が起り得る可能性を示唆 するものであることを褧付けていると考えられる。つぎ に中性, アルカリ性の領域では, 浱度による規則的な電 位の変化は見られない。これらの領域では，水酸イオン の放電による酸素の発生は容易に起るであろう。しかし 酢酸イオンを含めばこのイオンの吸着により酸素の発生 は抑制され，その結果としてブランク液よりも貴な電位 を示していると考えられる。 またこれらの領域で濃度に より電位が規則的に変化しないのは, 水酸イオンの放電 


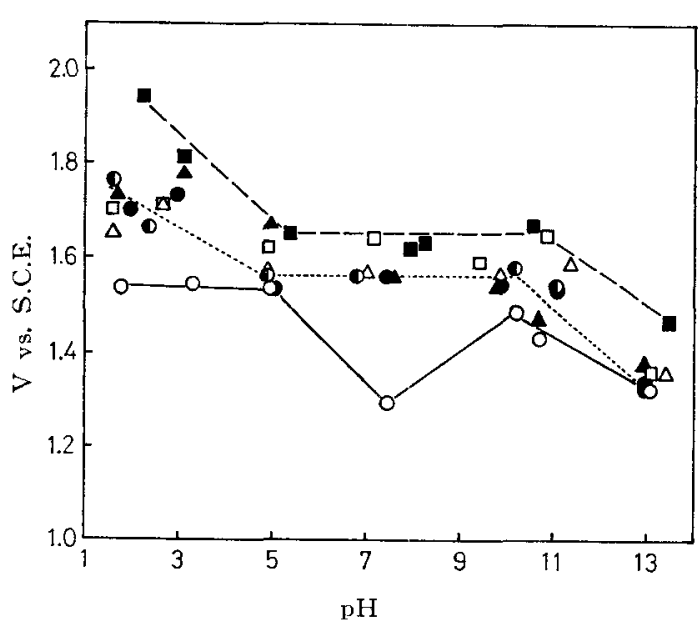

Fig. 1 Build up potential vs. $\mathrm{pH}$ at a platinum anode

$\bigcirc:$ Blank, $\bigcirc: 0.01 M, \triangle: 0.05 M, \square: 0.1 M$

: $0.5 \mathrm{M}, \triangle: 1 \mathrm{M}, \mathbf{\square}: 5 \mathrm{M}$

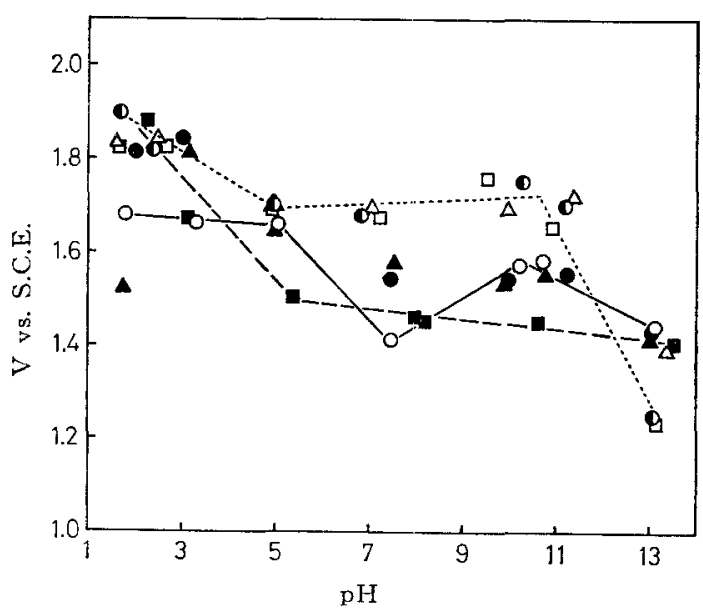

Fig. 2 Build up potential vs. pH at a gold anode

$$
\begin{aligned}
& O: \text { Blank, } D: 0.01 M, \triangle: 0.05 M, \square: 0.1 M \\
& : 0.5 M, \triangle: 1 M, \square: 5 M
\end{aligned}
$$

反応が活発になるためであると想われる。

他の電極では，白金で見られたような酢酸塩の添加に よる影響ははっきり認められない。

金電極 (Fig. 2) の場合は，湮度の変化により電位の 規則的変化はほとんど見られない.これまでの研究に著 者らが使用した電解液は弱酸性のむのであったことを孝 虑して，いま $\mathrm{pH}$ が5のときの電位に注目すると，Fig． $2 の \mathrm{pH}$ が 5 に掠いて，濃度の変化に立ち上がり電位 海無関係であり，各濃度についてのほとんどの電位がブ ランク液の值に近い。

パラジウム電極については, 金と同様, 濃度の変化に
よる電位の規則的変化はほとんど見られないが，ただ $\mathrm{pH}$ が 3 付近でいくらか電位の濃度依存性が認められ る.しかし $\mathrm{pH}$ が5では金とまったく同様に濃度による 影響は見られず，ほとんどの電位がブランク液の值に近 似している. したがって金とパラジウムの $\mathrm{pH}$ が5のと きのよらに, 各濃度についての電位がブランク液の電位 に近かった事実は, 酢酸塩水溶液中での反応が水酸イ才 ンの放電による酸素発生反忘だけであることの傍証にな るものと考えられる。

二酸化鉛電極については，立ち上がり電位は多様に複 雑な変化を示していることが見られた。この理由につい てはいまのところ不明であり，これだけの結果からは説 明も不可能と考えられる。

黒鉛電極についてはパラジウムと同様 $\mathrm{pH}$ が 3 付近で いくら加電位の濃度依存性が認められる。

以上のことより，白金はもちろんのことすべての電極 で其通していることは, $\mathrm{pH}$ が 13 のときには醀酸イ才 ンを含んでいてもその立ち上がり電位はブランク液の值 に近い值が得られたことである.これは電極反応として 水酸イオンの放電による酸素発生反応だを考慮すれば たりることを示するのと考えられる.

\section{2 酶酸イオンの電極表面被覆率}

酶酸イオンによる電極被覆率 $\theta$ は, 侄々木らの方 法112,12) と同様，つぎの式によって求めた。

$$
\left[i / i_{\mathrm{o}}\right]_{E=\mathrm{const}}=1-\theta
$$

ここで， $i_{0}$ は䤏酸イオンを含まないブランク溶液の酸 素発生電流， $i$ は酢酸イオンの共存によって酸素発生反 応が抑制されたときの電流を示す，なおこのとき電極の 電位 $E$ は一定として求める．もちろんこれらの電流值 は立ち上がり電位を調べたときに求めた電流一電位曲線 より読み取ったものである。

Fig. 3 は白金電極についての酶酸塩濃度に対する被 覆率を示す.この図は, 前の Fig. 1 において酢酸塩濃 度による笔位の規則的変化が認められた $\mathrm{pH} 3$ と 5 につ いて検討したものである。図から明らかなるらに， $\mathrm{pH}$ が 3 や 5 では酢酸塩濃度が $1 M$ に達すると $\theta$ は 0.7 以上となってほぼ定常状態を示している。なお $\mathrm{pH}$ が同 じでも電位がたとえば $1.7 \mathrm{~V}$ より $1.9 \mathrm{~V}$ のきの $\theta$ が高くなっている.これらの事実により，酢酸塩のコル ベ反店の最適条件として， $\mathrm{pH}$ は 5 以下で，酢酸塩の濃 度は $1 M$ 以上，それに陽極電位は $1.9 \mathrm{~V}$ 以上貴な電位 で行えばよいであろうと提案することができる。

つぎに,この $\theta$ に関して酢酸イオンの電極への吸着は どのような型のものであるかを考えてみることにする。

Fig. 4 は白金表面での被覆菜に関する酰酸塩漂度の役 割を示す. 前の Fig. 3 では， $1 M$ 以上で $\theta$ が一定值 を示すことが明らかになっているので， $1 M$ 以下の酢酸 塩濃度での吸着状態を見るのが適当であると考え, この 


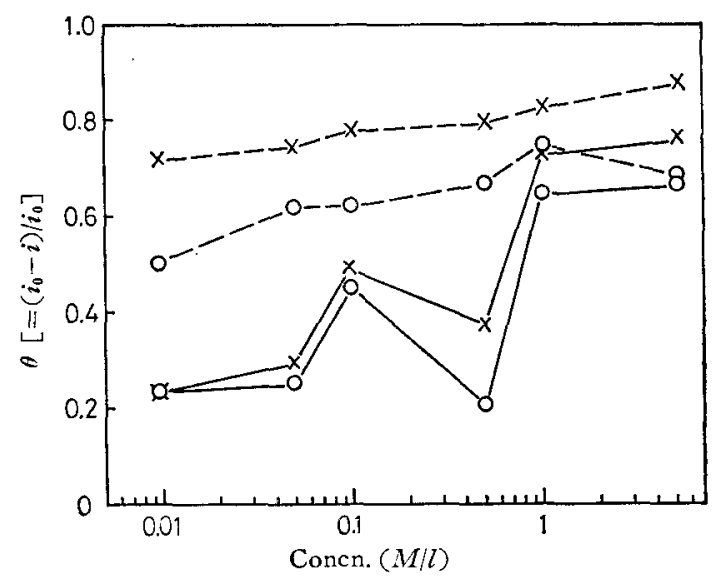

Fig. 3 Coverage vs, acetate concentration at a platinum anode
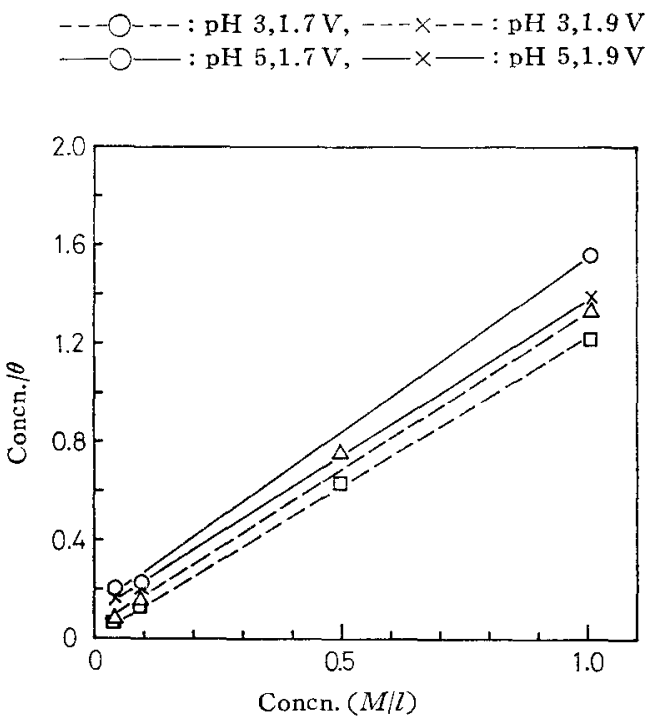

Fig. 4 Relation between acetate concentration and the coverage at a platinum surface

$$
-\triangle-1 \mathrm{pH} 3,1.7 \mathrm{~V},--\square--: \mathrm{pH} 3,1.9 \mathrm{~V}
$$

Fig. 4 では $1 M$ 以下の酶酸塩濃度を対象にした.この 网においては直線関係が見られたことにより，酸素発生 電位領域で吸着した酶酸イオンは，ラングミュアの吸着 等温式に從らことが認められた.このよらな傾向は， ブランク液にリン酸塩を用いて研究した棚ら ${ }^{12}$ の結果と よく一致していた.

これに対し Fig. 5 に示すよ で $\theta$ がゼロ以下となり，酢酸イオンの吸着はむろん問 題にならないようである。

しかし，パラジウムでは $\mathrm{pH}$ が3のときに，白金で見

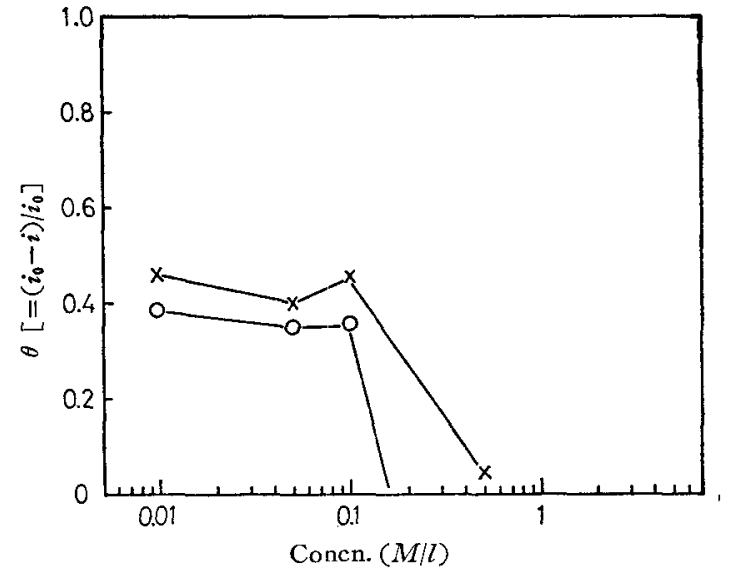

Fig. 5 Coverage vs, acetate concentration at a gold anode

$\mathrm{O}: \mathrm{pH} 5,1.7 \mathrm{~V}, \quad \times: \mathrm{pH} 5,1.9 \mathrm{~V}$

られたと同様ラングミュアの等温式に従うようであり， このことは貴な電位域ではパラジウムが白金と同じよう な挙動を示すという杉野らいの報告を説明するための興 味ある結果と考えた。

また黒鉛では，pH が5のとき $\theta$ の值は高濃度にな っても全般的に大きくはないが，貴な電位になるほど $\theta$ は高くなり，0.05M 以上でほぼラングミュアの等温式 に従らようである。このようなことにより，黑鉛では酢 酸イオンの吸着の影響优，定電位電解生成物として酢酸 メチルが得られている はできないすのと考えられる。

\section{4 総 括 (Summary)}

ブランク液としての硫酸カリウム水溶液に酢酸塩を加 え，これらの電解液の $\mathrm{pH}$ を変化させたときの白金につ いて，また比較参考のために金，パラジウム，二酸化鉛 および黑鉛陽極につい下の電流-電位曲線を電位走查法 により测定し，つぎの結果它得た。

(1) ブランク液では， $\mathrm{pH}$ が 2〜5 の範团で水酸イオ ンの放電による酸素発生電位は各電極特有の一定檤走示 した. 一定值の電位はパラジウムく白金く黒鉛く金く二 酸化鉛の順に貴な電位になっていた。また pH が 13 に 掞ける立ち上がり電位は酸素発生だけの本来の電位を示 していると考えられる。

（2）酢酸㷪添加液について白金では， $\mathrm{pH}$ が5以下に おける立ち上がり電位は滈濃度になるほど貴な電位に移 行した.この事実は，弱酸性域でコルベ反応が起り得る 可能性定示唆するものであることを裹付けていると考え られる。 
（3）白金につケての被覆率日は， $\mathrm{pH}$ が3 5 では 酶酸塩濃度が $1 M$ になって一定值に達した。また, $\theta$ は 贵な電位であるほど高い値が得られた。ここれらの吸着は ラングミュアの吸着等温式に從らことが示された。

本研究を行うにあたり，ご指導を賜かった東京工業大学関根

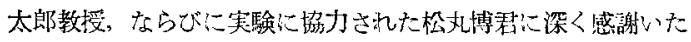
します。

(Received Jan. 10,1972)

1) 関根功, 本誌 41，376(1973).

2) 元來信一, 有機合成化学 24, 755 (1.966).

3）関根 功, 関根太郎, 本誌 37, 131 (1969).
4) 関根 功, 関根太郎, 木誌 36, 286 (1968).

5) F.G. Will, C.A. Knorr, Z. Elektrochem. 64, 258, 270(1960).

6) I. Sekine, T. Sekine, J. Electrochem. Soc. Japan 36, 201 (1968).

7) J.P. Hoare, Electrochim. Acta 11, 203 (1966).

8) J.P. Hoare, J. Electroanal. Chem. 12, 260 (1966).

9) J.P. Hoare, "The Electrochemistry of Oxygen", p.102(1968), Interscience Pub.

10) K. Sugino, T. Sekine, N. Sato, Electrochem. Tech. 1, 112 (1963).

11）传々木和夫，泉生一郎，大橋那夫，上村玩也，長浦茂男，日化誌 87, 918 (1966)

12）棚 章, 井関 進, 大槁邦夫, 長浦茂男, 本誌 37, 41 (1969).

13）杉野喜一郎, 関根太郎, ポーラロクラフィー第 3 集（化学の領域增 刊69号) p. 145 (1965).

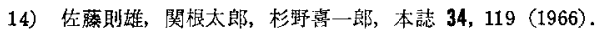

\title{
Polarographic Studies on Oxidation of Hydroquinone due to Atmospheric Oxygen
}

\author{
Gorou ARAI* and Hiroshi HAMANo*
}

\begin{abstract}
Hydroquinone is stable in acidic buffer solutions, but unstable in basic buffer solutions, which become brown due to oxiclation. The present investigation was undertaken to study the oxidation process of hydroquinone by the polarographic method with a dropping mercury electrode. The presence of $p$-quinone and hydrogen peroxide was confirmed by the determination of D.C and A.C polarograms in the course of the oxidation. From the fact that the half-wave potential and the peak potential of the oxidized products agreed well with those of 1,2,4-trihydroxybenzene, it was concluded that the reaction of $p$-quinone with hydrogen peroxide gave hydroxy-p-quinone. It was found that the decrease of $p$-quinone in the presence of hydrogen peroxide in neutral buffer solutions, in which p-quinone was stable, was accelerated by the formation of hydroxy- $p$-quinone, which was produced by the reaction of $p$-quinone with hydrogen peroxide.
\end{abstract}

\section{1 緒 言 (Introduction)}

ハイドロキノンの水銀電極界西における挙動について の研究は, Breyer ら"), や Bauer ${ }^{21}$ によってなされ， 八イドロキノンの電極表面一の吸着が報告されている. また近年, Hillson ${ }^{3 \gamma}$ は，電気毛管曲線を測定すること

* 神奈川大学工学部 (神奈川県横兵市神奈川区六角棈) Department of Applied Chemistry, FFaculty of Engineering, Kanagawa University (Rokkakubashi Kanagawa-ku Yokohama)
により，その吸着方向についての報告をしている、ハイ ドロキノンの電極界面における研究は, このように, 吸 着・脱着現象, 酸化体による電極のコンタミネーショ ン，電極界面における物質移動などに関して興味ある報 告がなされている，筆者らは，この電極界面に抢ける物 翼移動を，写真現像機構の見地から検討するため，ハ1 ドロキノンのポーラログラフィーにつレて Breyer らと 類似の実験を試みた.アルカリ性溶液では再現性が覀る いが，この原因汢溶存酸续によるハイドロキノンの酸化 